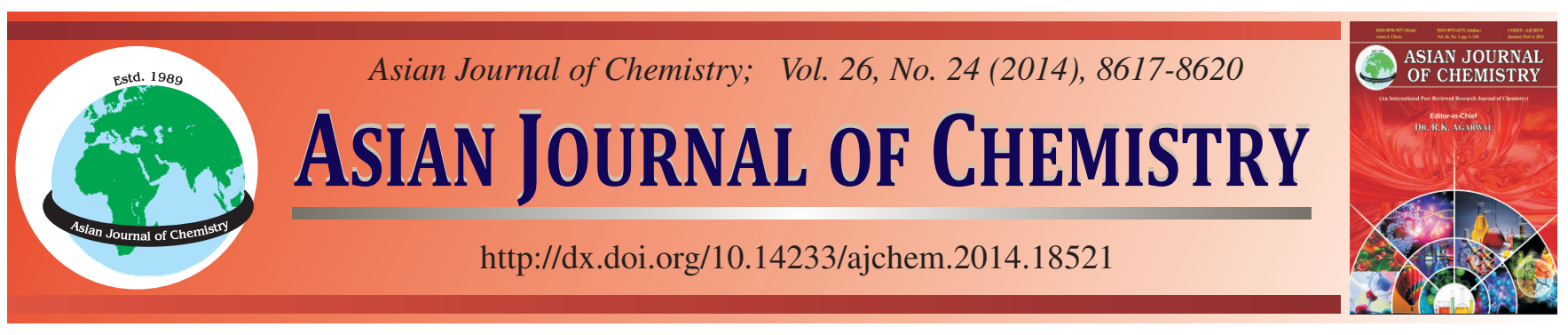

\title{
Hydrothermal Syntheses and Crystal Structure of Hybrid Material Based on Keggin Cluster Modified by Nickel Complex
}

\author{
Y.N. ZhANG ${ }^{*}$, Y.J. Zhang, D. Li, L. ZhANG, M. YANG and H. LiU
}

College of Pharmacy, Jiamusi University, Jiamusi 154007, Heilongjiang Province, P.R. China

*Corresponding author: Tel/Fax: +86 454 8610678; E-mail: zhangyunan79@163.com

\begin{abstract}
A new organic-inorganic hybrid compound based on the Keggin polyoxometalates modified by nickel and N-ligand organic moiety: $\left[\mathrm{Ni}(\text { phen })_{3}\right]_{2}\left[\mathrm{PMo}_{11}{ }^{\mathrm{VI}} \mathrm{Mo}^{\mathrm{V}} \mathrm{O}_{40}\right](\mathbf{1})$ (phen = 1,10-phenanthroline) has been hydrothermally synthesized and characterized structurally. It crystallizes in the triclinic space group P-1 with $\mathrm{a}=12.203(2), \mathrm{b}=13.907(2), \mathrm{c}=14.438(3) \AA ; \alpha=104.859(2), \beta=108.777(2), \gamma=$ 93.376(2), $\mathrm{V}=2215.3(7) \AA^{3}, \mathrm{C}_{72} \mathrm{H}_{48} \mathrm{~N}_{12} \mathrm{O}_{40} \mathrm{PMo}_{12} \mathrm{Ni}_{2}, \mathrm{Mr}=3020.85, \mathrm{Z}=1, \mathrm{Dc}=2.264 \mathrm{~g} / \mathrm{cm}^{3}, \mathrm{~m}=2.164 \mathrm{~mm}^{-1}, \mathrm{~F}(000)=1459, \mathrm{R}=0.0355$ and $w R=0.0937$ for 6948 observed reflections with $\mathrm{I}>2 \sigma(\mathrm{I})$. The compound $\mathbf{1}$ consists of discrete polyoxoanions $\left[\mathrm{PMo}_{11}{ }^{\mathrm{VI}} \mathrm{Mo}^{\mathrm{V}} \mathrm{O}_{40}\right]^{4}$ and counter cations $\left[\mathrm{Ni}(\mathrm{phen})_{3}\right]^{2+}$. The electrochemical property of compound $\mathbf{1}$ has been studied in the paper.
\end{abstract}

Keywords: Keggin structure, Polyoxometalates, Nickel, Hydrothermal synthesis, Electrochemical property.

- - - - - - - - - - - - - - - - - - - - - - - - - -

\section{INTRODUCTION}

As an interesting class of metal oxide clusters, polyoxometalates (POMs) can be used as one kind of inorganic building blocks to build novel functional organic-inorganic solid materials, due to quite a number of valuable properties of these compounds such as catalysis, electrochemistry, photochemical and magnetism ${ }^{1-4}$. Design and synthesis of novel functional organic-inorganic hybrid materials based on polyoxometalates (POMs) is still a challenge ${ }^{5,6}$. Currently, modification of polyoxometalates with transition metal complexes of various organic groups under hydrothermal synthesis condition has been proven to be an effective route to prepare novel functional Keggin POM hybrids ${ }^{7,8}$. Although many Keggin polyoxometalates modified by $3 d$ transition metal complexes have been reported, Keggin polyoxo-metalates modified by nickel complexes $\left(\left[\mathrm{Ni}(\text { phen })_{3}\right]^{2+}\right)$ are few ${ }^{9-11}$. In fact, our group has been focused on exploring the possible effect of N-ligand organic moiety in the crystal engineering of novel functional organicinorganic hybrid materials based on polyoxometalates under hydrothermal conditions ${ }^{12-15}$. So, in this paper, as a continuation of our research, we report a novel organic-inorganic hybrid materials based on polyoxo-metalates: $\left[\mathrm{Ni}(\text { phen })_{3}\right]_{2}[\mathrm{P}-$ $\left.\mathrm{Mo}_{11}{ }^{\mathrm{VI}} \mathrm{Mo}^{\mathrm{V}} \mathrm{O}_{40}\right]$ (1). The compound (1) consists of Keggin-type polyoxoanion $\left[\mathrm{PMo}_{11}{ }^{\mathrm{VI}} \mathrm{Mo}^{\mathrm{V}} \mathrm{O}_{40}\right]^{4-}$ and counter cations $\left[\mathrm{Ni}(\text { phen })_{3}\right]^{2+}$.

\section{EXPERIMENTAL}

General procedure: All chemicals were purchased commercially and used without further purification. Elemental analyses were performed on a Perkin-Elmer $2400 \mathrm{CHN}$ Elemental Analyzer (C, $\mathrm{H}$ and $\mathrm{N}$ ); XPS analysis was performed on a VGESCALABMK II spectrometer with an $\operatorname{MgK}_{\alpha}(1253.6$ $\mathrm{eV}$ ) achromatic X-ray source. The vacuum inside the analysis chamber was maintained at $6.2 \times 10^{-6} \mathrm{~Pa}$ during analysis. IR spectra were obtained on an Alpha Centaurt FT/IR spectrometer with $\mathrm{KBr}$ pellet in the $4000-400 \mathrm{~cm}^{-1}$ region. Thermogravimetric analyses were recorded in a dynamic nitrogen atmosphere with a heating rate of $10{ }^{\circ} \mathrm{C} / \mathrm{min}$ using a Mettler TGA/SDTA851e thermal analyzer. Cyclic voltammograms were obtained with a CHI 660 electrochemical workstation at room temperature. Platinum gauze was used as counter electrode and $\mathrm{Ag} / \mathrm{AgCl}$ electrode was reference. A chemically bulkmodified carbon paste electrode (CPE) was used as working electrode.

Synthesis of the title compound: A mixture of $\mathrm{Na}_{2} \mathrm{MoO}_{4} \cdot 2 \mathrm{H}_{2} \mathrm{O}$ (1 mmol, $\left.0.242 \mathrm{~g}\right), \mathrm{MoO}_{3}(1 \mathrm{mmol}, 0.144 \mathrm{~g})$, $\mathrm{NiCl}_{3} \cdot 6 \mathrm{H}_{2} \mathrm{O}$ (1 mmol, $0.2377 \mathrm{~g}$ ), 1,10-phenanthroline (1 mmol, $0.198 \mathrm{~g})$, pyridine $(2 \mathrm{~mL})$ and $\mathrm{H}_{3} \mathrm{PO}_{4}(2 \mathrm{~mL}, 85 \%)$ was dissolved in $30 \mathrm{~mL}$ of water. The mixture was stirred for $2 \mathrm{~h}$ at room temperature and then heated in a $50 \mathrm{~mL}$ Teflon-lined stainless steel autoclave for 8 days at $180^{\circ} \mathrm{C}$. After slow cooling 
to room temperature, the solid product containing black green block shaped crystals were isolated in $31 \%$ yield (based on $\mathrm{Ni}$.

For $\mathrm{C}_{72} \mathrm{H}_{48} \mathrm{~N}_{12} \mathrm{O}_{40} \mathrm{PMo}_{12} \mathrm{Ni}_{2}$. Anal. Calcd (\%) : C, 28.63; H, 1.60; N, 5.56; found: C, 28.38; H, 1.94; N, 5.47. Infrared spectrum $\left(\mathrm{KBr}, v_{\max }, \mathrm{cm}^{-1}\right): 3750(\mathrm{w}), 3440(\mathrm{~s}), 2937(\mathrm{w})$, 2350(w), 1643(s), 1531(s), 1440(s), 1072(s), 996(s), 898(s), 809(s), 728(s).

X-Ray crystallography: Black green single crystal of the title compound $(0.32 \mathrm{~mm} \times 0.20 \mathrm{~mm} \times 0.18 \mathrm{~mm})$ was put on a Bruker SMART APEX II CCD diffractometer equipped with a graphite-monochromated $\mathrm{MoK}_{\alpha}$ radiation $(\lambda=0.71073$ $\AA$ ) by using a $\phi / \omega$ scan technique at room temperature. 6948 independent reflections $\left(\mathrm{R}_{\mathrm{int}}=0.0120\right)$ in the range $2.53<\theta<$ 24.00 with $-13<=\mathrm{h}<=13,-15<=\mathrm{k}<=15,-16<=1<=16$ were collected at 273(2) K. The structure was solved by direct methods with SHELXS-97 ${ }^{16}$.

The hydrogen atoms were assigned with common isotropic displacement factors and included in the final refinement by use of geometrical restrains, while the non-hydrogen atoms were treated with common anisotropic displacement factors and included in the final refinement with geometrical restrains. A full-matrix least-squares refinement on $\mathrm{F}^{2}$ was carried out using SHELXL-97 ${ }^{17}$. The final agreement factor values are $\mathrm{R}$ $=0.0355$ and $\mathrm{w} R=0.937$. Crystallographic data and refinement parameters are listed in Table-1. CCDC 1013742 contains the supplementary crystallographic data for this paper. These data can be obtained free of charge from The Cambridge Crystallographic Data Centre via www.ccdc.cam.ac.uk/data_request/ cif.

TABLE-1

CRYSTALLOGRAPHIC DATA FOR [Ni(phen $\left.)_{3}\right]_{2}\left[\mathrm{PMo}_{11}{ }^{\mathrm{VI}} \mathrm{Mo}^{\mathrm{v}} \mathrm{O}_{40}\right]$

\begin{tabular}{|c|c|}
\hline Compound & {$\left[\mathrm{Ni}(\text { phen })_{3}\right]_{2}\left[\mathrm{PMo}_{11}{ }^{\mathrm{Vl}} \mathrm{Mo}^{\mathrm{V}} \mathrm{O}_{40}\right]$} \\
\hline Color/shape & Black green/block \\
\hline Formula & $\mathrm{C}_{72} \mathrm{H}_{48} \mathrm{~N}_{12} \mathrm{O}_{40} \mathrm{PMo}_{12} \mathrm{Ni}_{2}$ \\
\hline Formula weight & 3020.85 \\
\hline Temperature (K) & $273(2)$ \\
\hline Wavelength $(\AA)$ & 0.71073 \\
\hline Crystal system & Triclinic \\
\hline Space group & P-1 \\
\hline Unit cell dimensions & $\begin{array}{l}\mathrm{a}=12.203(2) \AA \\
\mathrm{b}=13.907(2) \AA \\
\mathrm{c}=14.438(3) \AA \\
\alpha=104.859(2) \\
\beta=108.777(2) \\
\gamma=93.376(2)\end{array}$ \\
\hline Z Volume, $\AA^{3}$ & $12215.3(7)$ \\
\hline Calculated density $\left(\mathrm{mg} / \mathrm{m}^{3}\right)$ & 2.264 \\
\hline Absorption coefficient $\left(\mathrm{mm}^{-1}\right)$ & 2.164 \\
\hline $\mathrm{F}(000)$ & 1459 \\
\hline$\theta$ Range for data collection $\left({ }^{\circ}\right)$ & $2.53-24.00$ \\
\hline Reflections collected & 14038 \\
\hline Independent reflection & $6498[\mathrm{R}(\mathrm{int})=0.0120]$ \\
\hline Refinement method & Full-matrix least-squares on $\mathrm{F}^{2}$ \\
\hline Data/restraints/parameters & 6498/0/646 \\
\hline Goodness-of-fit on $\mathrm{F}^{2}$ & 1.000 \\
\hline Final $R$ indices $[I>2 \sigma(I)]$ & $\mathrm{R} 1=0.0353, \mathrm{wR} 2=0.0937$ \\
\hline $\mathrm{R}$ indices (all data) & $\mathrm{R} 1=0.0383, \mathrm{wR} 2=0.0957$ \\
\hline Largest diff. peak and hole & 1.410 and $-0.922 \mathrm{e} / \AA^{3}$ \\
\hline
\end{tabular}

Preparation of (1)-CPE: Compound 1 modified carbon paste electrode (1)-CPE was prepared as follows: $96 \mathrm{mg}$ of graphite powder and $4 \mathrm{mg}$ of compound $\mathbf{1}$ was mixed and ground together by agate mortar and pestle to achieve a uniform mixture and then added to $0.5 \mathrm{~mL}$ petrolin with stirring. The homogenized mixture was packed into a glass tube with $1 \mathrm{~mm}$ inner diameter and the tube surface was wiped with pan paper. Electrical contact was established with copper rod through the back of the electrode.

\section{RESULTS AND DISCUSSION}

Description of the crystal structure: Single crystal Xray diffraction analysis reveals that compound $\mathbf{1}$ consists of discrete polyoxoanions $\left[\mathrm{PMo}_{11}{ }^{\mathrm{VI}} \mathrm{Mo}^{\mathrm{V}} \mathrm{O}_{40}\right]^{4-}$ and counter cations $\left[\mathrm{Ni}(\text { phen })_{3}\right]^{2+}$ (Fig. 1). Selected bond lengths and angles are collected in Table-2. The polyoxoanion $\left[\mathrm{PMo}_{11}{ }^{\mathrm{VI}} \mathrm{Mo}^{\mathrm{V}} \mathrm{O}_{40}\right]^{4-}$ exhibits a disordered $\alpha$-Keggin structure. The central $\mathrm{P}$ atom is surrounded by a cube of eight oxygen atoms with site halfoccupied. The disordered $\left\{\mathrm{PO}_{4}\right\}$ tetrahedron is located in the center of host cage with P-O distance of 1.467(6)-1.603(6) $\AA$ and O-P-O bond angle in the range of 103.2(3)-115.9(3) ${ }^{\circ}$. All Mo atoms have a distorted $\left\{\mathrm{MoO}_{6}\right\}$ octahedral environment. The Mo-O distances can be grouped into three sets: Mo- $\mathrm{O}_{\mathrm{t}}$ (terminal) 1.647(4)-1.667(3) $\mathrm{A}$, Mo- $\mathrm{O}_{\mathrm{t}}$ (bridge) 1.837(5)$1.874(5) \AA$ and $\mathrm{Mo}_{\mathrm{t}}$ (central) 1.922(5)-1.951(5) $\mathrm{A}$. The assignments of oxidation state for Mo atoms are consistent with their coordination geometries and confirmed by XPS spectra. In the experiment, by the introduction of the reducer pyridine, one out of twelve Mo centers is in the +5 oxidation state and the others are in the +6 oxidation state, resulting in a mixed valence polyoxometalate. In the structure of the title compound, there exists complex cation $\left[\mathrm{Ni}(\text { phen })_{3}\right]^{2+}$. Each $\mathrm{Ni}$ atom is coordinated by six nitrogen atoms from three phen ligands to form a distorted $\mathrm{NiN}_{6}$ octahedron with an isolated complex cation. The Ni-N bond lengths range from 2.083(4) to 2.097(4) A.

IR spectra: IR spectra of compound 1 were carried out over the rang from 4000 to $400 \mathrm{~cm}^{-1}$ (Fig. 2). The strong bands at $1072,966,898,809$ and $728 \mathrm{~cm}^{-1}$ are ascribed to $\mathrm{v}_{\mathrm{as}}(\mathrm{P}-\mathrm{O})$, $\mathrm{v}_{\mathrm{as}}\left(\mathrm{Mo}-\mathrm{O}_{\mathrm{d}}\right), \mathrm{v}_{\mathrm{as}}\left(\mathrm{Mo}-\mathrm{O}_{\mathrm{b}}-\mathrm{Mo}\right), \mathrm{v}_{\mathrm{as}}\left(\mathrm{Mo}-\mathrm{O}_{\mathrm{c}}-\mathrm{Mo}\right)$ and $\mathrm{v}_{\mathrm{as}}(\mathrm{Ni}-\mathrm{N})$, respectively. The peaks at $3750-1080 \mathrm{~cm}^{-1}$ are characteristic for phenanthroline.

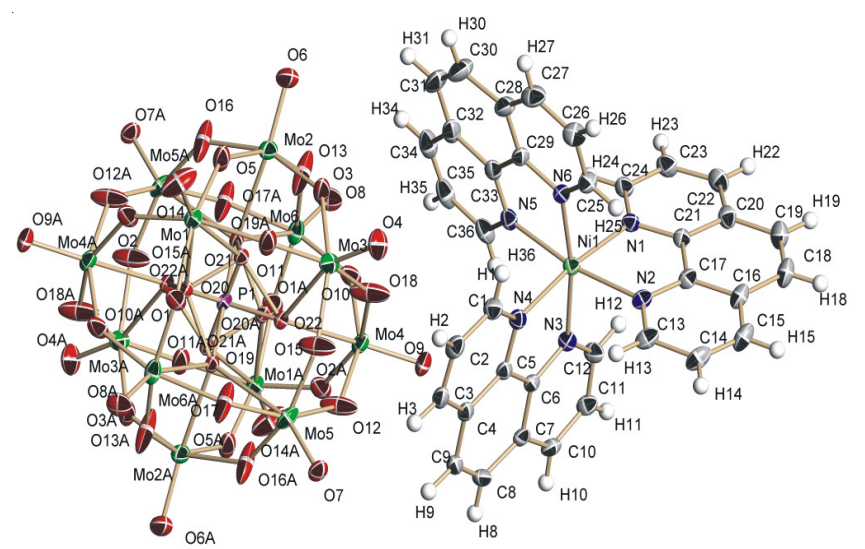

Fig. 1. Molecular structure of $\left[\mathrm{Ni}(\text { phen })_{3}\right]_{2}\left[\mathrm{PMo}_{11}{ }^{\mathrm{VI}} \mathrm{Mov}_{\mathrm{V}} \mathrm{O}_{40}\right]$ in the solid state. $30 \%$ probability ellipsoids 


\begin{tabular}{|c|c|c|c|}
\hline \multicolumn{4}{|c|}{ 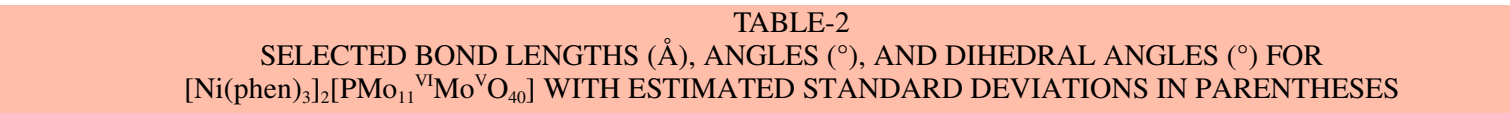 } \\
\hline Bond & $\mathrm{d},(\AA)$ & Bond & $\mathrm{d},(\AA)$ \\
\hline $\mathrm{Mo}(1)-\mathrm{O}(2)$ & $1.855(4)$ & $\mathrm{Mo}(2)-\mathrm{O}(13)$ & $1.869(5)$ \\
\hline $\mathrm{Mo}(3)-\mathrm{O}(11)$ & $1.848(5)$ & $\mathrm{Mo}(4)-\mathrm{O}(18)$ & $1.837(5)$ \\
\hline $\mathrm{Mo}(5)-\mathrm{O}(16) \# 1$ & $1.874(5)$ & $\mathrm{Mo}(1)-\mathrm{O}(11)$ & $1.945(4)$ \\
\hline $\mathrm{Mo}(2)-\mathrm{O}(5)$ & $1.926(5)$ & $\mathrm{Mo}(3)-\mathrm{O}(18)$ & $1.947(5)$ \\
\hline $\mathrm{Mo}(4)-\mathrm{O}(2) \# 1$ & $1.951(5)$ & $\mathrm{Mo}(5)-\mathrm{O}(15)$ & $1.922(5)$ \\
\hline $\mathrm{Mo}(1)-\mathrm{O}(14)$ & $1.647(4)$ & $\mathrm{Mo}(2)-\mathrm{O}(6)$ & $1.677(4)$ \\
\hline $\mathrm{Mo}(3)-\mathrm{O}(4)$ & $1.657(4)$ & $\mathrm{Mo}(4)-\mathrm{O}(9)$ & $1.670(4)$ \\
\hline $\mathrm{Mo}(5)-\mathrm{O}(7)$ & $1.667(3)$ & $\mathrm{P}(1)-\mathrm{O}(21) \# 1$ & $1.467(6)$ \\
\hline $\mathrm{P}(1)-\mathrm{O}(19)$ & $1.603(6)$ & $\mathrm{Ni}(1)-\mathrm{N}(6)$ & $2.083(4)$ \\
\hline $\mathrm{Ni}(1)-\mathrm{N}(4)$ & $2.089(4)$ & $\mathrm{Ni}(1)-\mathrm{N}(5)$ & $2.094(4)$ \\
\hline $\mathrm{Ni}(1)-\mathrm{N}(2)$ & $2.096(4)$ & $\mathrm{Ni}(1)-\mathrm{N}(3)$ & $2.097(4)$ \\
\hline $\mathrm{Ni}(1)-\mathrm{N}(1)$ & $2.101(4)$ & $\mathrm{N}(2)-\mathrm{C}(13)$ & $1.325(7)$ \\
\hline $\mathrm{N}(4)-\mathrm{C}(5)$ & $1.362(7)$ & $\mathrm{C}(31)-\mathrm{C}(30)$ & $1.318(11)$ \\
\hline $\mathrm{C}(32)-\mathrm{C}(31)$ & $1.444(11)$ & - & - \\
\hline Angle & $\omega,\left(^{\circ}\right)$ & Angle & $\omega,\left(^{\circ}\right)$ \\
\hline $\mathrm{O}(22)-\mathrm{P}(1)-\mathrm{O}(19) \# 1$ & $103.2(3)$ & $\mathrm{O}(21) \# 1-\mathrm{P}(1)-\mathrm{O}(20)$ & $115.9(3)$ \\
\hline $\mathrm{O}(9)-\mathrm{Mo}(4)-\mathrm{O}(10)$ & $100.6(2)$ & $\mathrm{O}(8)-\mathrm{Mo}(6)-\mathrm{O}(13)$ & $101.0(3)$ \\
\hline $\mathrm{O}(6)-\mathrm{Mo}(2)-\mathrm{O}(3)$ & $102.0(2)$ & $\mathrm{O}(4)-\mathrm{Mo}(3)-\mathrm{O}(18)$ & $102.3(3)$ \\
\hline $\mathrm{O}(7)-\mathrm{Mo}(5)-\mathrm{O}(16) \# 1$ & $102.7(3)$ & $\mathrm{O}(7)-\mathrm{Mo}(5)-\mathrm{O}(17)$ & $102.8(2)$ \\
\hline $\mathrm{O}(14)-\mathrm{Mo}(1)-\mathrm{O}(5)$ & $102.9(3)$ & $\mathrm{O}(4)-\mathrm{Mo}(3)-\mathrm{O}(15)$ & $103.1(3)$ \\
\hline $\mathrm{C}(5)-\mathrm{N}(4)-\mathrm{Ni}(1)$ & 112.1(3) & $\mathrm{C}(29)-\mathrm{N}(6)-\mathrm{Ni}(1)$ & $113.0(3)$ \\
\hline $\mathrm{N}(6)-\mathrm{C}(29)-\mathrm{C}(33)$ & $116.9(5)$ & $\mathrm{N}(3)-\mathrm{C}(12)-\mathrm{C}(11)$ & $123.4(5)$ \\
\hline $\mathrm{N}(2)-\mathrm{Ni}(1)-\mathrm{N}(1)$ & $79.51(16)$ & $\mathrm{N}(4)-\mathrm{Ni}(1)-\mathrm{N}(2)$ & $96.09(17)$ \\
\hline
\end{tabular}

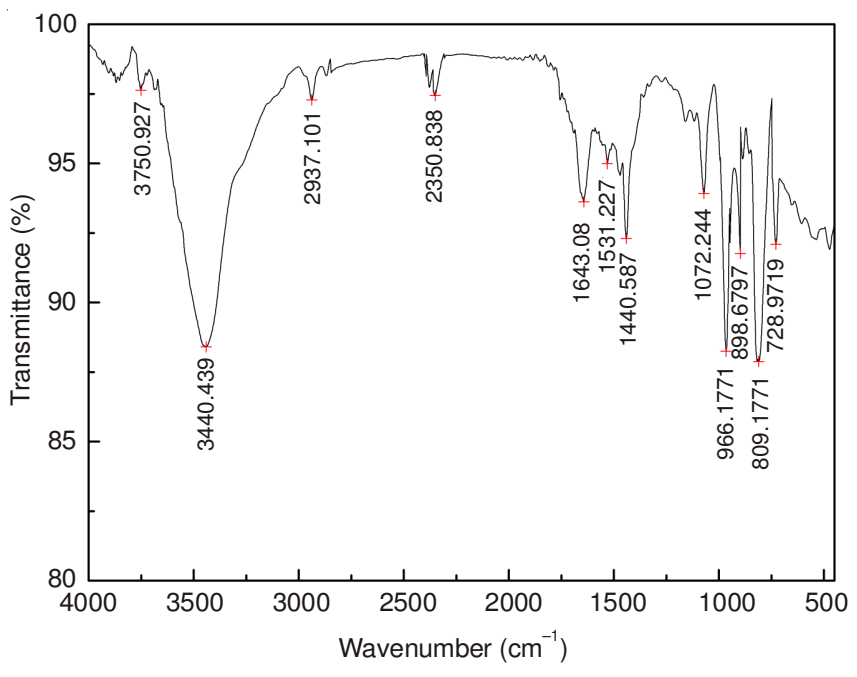

Fig. 2. IR spectra of $\left[\mathrm{Ni}(\text { phen })_{3}\right]_{2}\left[\mathrm{PMo}_{11}{ }^{\mathrm{VI}} \mathrm{Mov}_{\mathrm{v}} \mathrm{O}_{40}\right]$

Thermal analysis: The TG analyses were carried out over the temperature range from 20 to $800{ }^{\circ} \mathrm{C}$. The TG curve of compound 1 shows continuous weight loss over the temperature range from 20 to $800{ }^{\circ} \mathrm{C}$ (Fig. 3). The region at about 35$730{ }^{\circ} \mathrm{C}$ with a mass loss of $64.4 \%$ (calcd. $64.3 \%$ ) is due to release of phen molecules coordinated with Ni.

Cyclic voltammetry: The cyclic voltammetry of compound 1 was measured in the potential rang from -0.2 to $0.55 \mathrm{v}$. The typical cyclic voltammetric behaviour of (1)-CPE was explored in $1 \mathrm{~mol} \mathrm{~L}^{-1} \mathrm{H}_{2} \mathrm{SO}_{4}$ aqueous solution at different scan rates. In Fig. 4, there are four reversible redox peaks appeared and mean peak potentials $\mathrm{E}_{1 / 2}=\left(\mathrm{E}_{\mathrm{pc}}+\mathrm{E}_{\mathrm{pa}}\right) / 2$ are $0.359,0.208$ and $-0.052 \mathrm{~V}$, respectively. Redox peaks I-I', II-II' and III-III' should be ascribed to three consecutive 2-electron proesses of Mo,

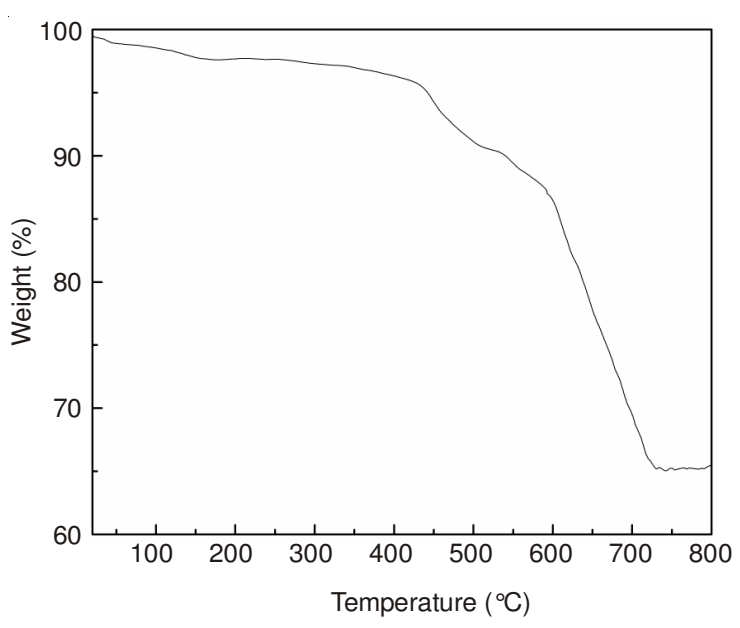

Fig. 3. TG curve of $\left[\mathrm{Ni}(\text { phen })_{3}\right]_{2}\left[\mathrm{PMo}_{11}{ }^{\mathrm{VI}} \mathrm{Mo}_{\mathrm{V}} \mathrm{O}_{40}\right]$

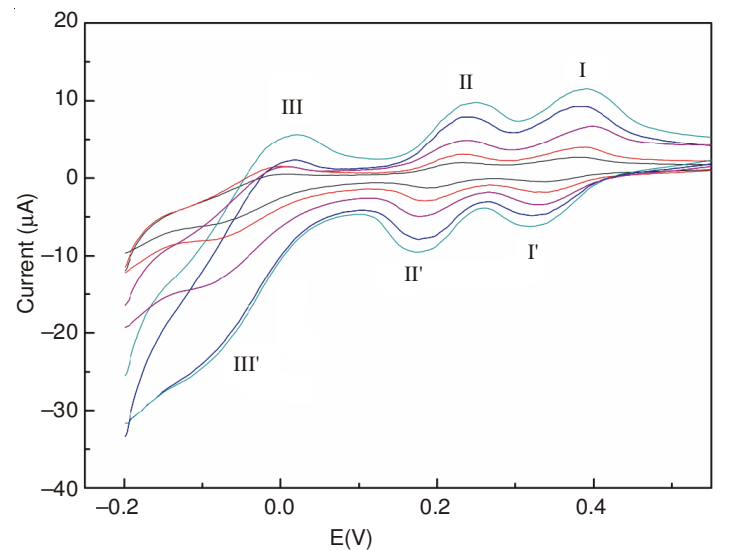

Fig. 4. Cyclic voltammograms for (1)-CPE was explored in $1 \mathrm{~mol} \mathrm{~L}^{-1} \mathrm{H}_{2} \mathrm{SO}_{4}$ aqueous solution at different scan rates. (from inner to outer: 0.02 , $\left.0.04,0.06,0.08,0.10 \mathrm{~V} \mathrm{~s}^{-1}\right)$ 
respectively. The cathodic peak potentials shift toward the negative and the corresponding anodic peak potentials to the positive direction. The peak-to-peak separation between the corresponding cathodic and anodic peaks increases with increasing scan rate, all but the mean peak potentials do not change.

\section{Conclusion}

In summary, a novel supramolecular organic-inorganic hybrid compound based on the Keggin polyoxometalates modified by nickel and 1,10-phenanthroline has been successfully prepared and structurally characterized. This work proves that the hydrothermal synthesis techniques is an effective route to prepare novel organic-inorganic hybrid materials based on polyoxometalates in combination with transition metal complexes of N-ligand organic moiety.

\section{ACKNOWLEDGEMENTS}

The work was supported by Scientific Research Fund of Heilongjiang Provincial Education Department (No. 12511543).

\section{REFERENCES}

1. F.Q. Zhang, X.M. Zhang, R.Q. Fang and H.S. Wu, Dalton Trans., 39 8256 (2010).

2. J.Q. Sha, M.T. Li, J.W. Sun, Y.N. Zhang, P.F. Yan and G.M. Li, Dalton Trans., 42, 7803 (2013).
3. Y.B. Huang, J.X. Chen, T.Y. Lan, X.Q. Lu, C.X. Wei, Z.S. Li and Z.C. Zhang, J. Mol. Struct., 783, 168 (2006).

4. Z.M. Hao, Q.S. Dong, L. Zhang, Y. Zhang and F. Luo, CrystEngComm, 12, 977 (2010).

5. D.L. Long, E. Burkholder and L. Cronin, Chem. Soc. Rev., 36, 105 (2006).

6. F.M. Santos, P. Brandão, V. Félix, A.M.V. Cavaleiro, E. de Matos Gomes and M.S. Belsley, J. Mol. Struct., 963, 267 (2010).

7. J. Thomas and A. Ramanan, Cryst. Growth Des., 8, 3390 (2008).

8. Y.G. Li, L.M. Dai, Y.H. Wang, X.L. Wang, E.B. Wang, Z.M. Su and L. $\mathrm{Xu}$, Chem. Commun. (Camb.), 2593 (2007).

9. J.Q. Sha, J. Peng, H.S. Liu, J. Chen, A.X. Tian, B.X. Dong and P.P. Zhang, J. Coord. Chem., 61, 1221 (2008).

10. S. Chang, C. Qin, E.B. Wang, Y.G. Li and X.L. Wang, Inorg. Chem. Commun., 9, 727 (2006).

11. Y.-B. Liu, L.-M. Duan, X.-M. Yang, J.-Q. Xu, Q.-B. Zhang, Y.-K. Lu and J. Liu, J. Solid State Chem., 179, 122 (2006).

12. Y.N. Zhang, B.B. Zhou, J.Q. Sha, Z.H. Su and J.W. Cui, J. Solid State Chem., 184, 419 (2011).

13. Y.N. Zhang, B.B. Zhou, J.Q. Sha, Z.H. Su and H. Liu, Inorg. Chem. Commun., 13, 550 (2010).

14. Y.N. Zhang, B.B. Zhou, Y.G. Li, Z.H. Su and Z.F. Zhao, Dalton Trans., 9446 (2009).

15. Y.N. Zhang, B.B. Zhou, Z.H. Su, Z.F. Zhao and C.X. Li, Inorg. Chem. Commun., 12, 65 (2009).

16. G.M. Sheldrick, SHELXS 97, Program for the Solution of Crystal Structures, University of Gottingen, Germany (1997).

17. G.M. Sheldrick, SHELXL 97, Program for the Refinement of Crystal Structures, University of Gottingen, Germany (1997). 